This is the post-peer review final draft of a paper published in Journal of Environmental

Engineering and Science. The final publication is published by NRC Research Press Canadian Science Publishing and available via http://dx.doi.org/10.1680/jenes.16.00025

\title{
Alleviating health risks associated with rainwater harvesting
}

Sarah Ward ${ }^{1 *}$ BSc MRes PhD CEnv CWEM AHEA, David Butler ${ }^{1}$ BSc MSc DIC PhD FREng CEng CEnv CWEM FICE FICIWEM FHEA, Bebhinn Daly ${ }^{2}$ BSc, Ann Marie Deegan ${ }^{2}$ BSc PhD, Ana Carolina Maganha de Almeida ${ }^{2}$ BSc MSc PhD , lain Lennox ${ }^{2}$

${ }^{1}$ Centre for Water Systems, College of Engineering, Mathematics and Physical Sciences, University of Exeter, Harrison Building, North Park Road, Exeter, EX4 4QF, UK

${ }^{2}$ RainSafe/Ozone Industries Ireland, Newtown Business Park, Newtownmountkennedy, Co. Wicklow, Ireland

*Corresponding author: sarah.ward@exeter.ac.uk

\begin{abstract}
Perceived and real public health risks associated with the quality of water from alternative water sources and supply systems, such as rainwater harvesting (RWH) and greywater reuse, continue to restrict their uptake in many countries. One option to alleviate these health risks is to treat alternative water to potable standard at the point of use (POU) as opposed to the point of supply, as undertaken in centralised systems. This paper presents the results of three international empirical field trials of a novel POU RWH treatment device. Results indicate that where the harvested rainwater did not contain elevated levels of pesticides or physicochemical determinands, the POU device was able to reduce levels in outlet water to meet UK, EU and WHO potable standards. Regarding microbiological determinands, such as total viable counts and coliforms, and microbial pathogens, such as Pseudomonas aeruginosa and Legionella spp, the device achieved reduction to potable standard and full pathogen removal, respectively. Thus whilst it is possible to treat harvested rainwater to potable standard with a POU device, whether it is desirable to do so to alleviate risks for all end uses remains a question for further debate.
\end{abstract}

\section{Keywords}

Field testing \& monitoring, public health, water supply

\section{Introduction}

Rainwater harvesting (RWH) enables the collection and storage of roof runoff to supplement potable water with harvested rainwater. RWH is used globally for non-potable and potable end-uses, depending on national and regional laws, standards and guidelines. For example, RWH is actively promoted in Texas (Texas Water Development Board, 2005) and there are standards relating to its use in the UK (BSI, 2013), but it is legally prohibited in Kenya (Amos et al., 2016). The application of RWH also varies internationally, for example in the UK, USA and parts of Australia, RWH is most often considered for non-potable end uses such as irrigation, toilet flushing and vehicle washing (Ward et al., 2010, 2015; Thomas et al., 2014; Amos et al., 2016). However, in parts of Bangladesh, India and Australia, RWH is most often considered for potable end uses due to groundwater becoming increasingly contaminated with arsenic or a lack of alternative sources (Islam et al., 2010; Amos et al., 2016). 
Research into the quality of harvested rainwater and health risks associated with potable and nonpotable end uses has been undertaken in a range of contexts (Lye, 2002; CRC, 2005; Meera and Ahmed, 2006; Fewtrell and Kay, 2007a; Ahmed et al, 2011; Ward, 2010 and de Kwaadsteniet et al., 2013). This is in recognition that although rainwater generally does not contain many contaminants, except those derived from the atmosphere, once it is harvested and stored the quality may deteriorate, particularly from a microbiological perspective, due to a range of variables. Sources of contamination from the catchment can include wind-blown particulates and animal and bird faeces, which have particular implications for microbiological quality, leading to potential health risks (WHO, 2008). Lye (2002) reviewed a number of studies across the USA, Australia, Thailand and Micronesia between 1983 and 1996 and concluded that whilst some RWH systems were prone to containing high levels of faecal coliforms others were not, highlighting the site-specific nature of harvested rainwater quality. This was reinforced by the Australian Cooperative Research Centre for Water Quality and Treatment (CRC, 2005), Fewtrell and Kay (2007a), Meera and Ahmed (2006) and more recently by Ahmed et al (2011) who undertook a review of studies in similar contexts between 1978 and 2009 linking the microbiological quality of harvested rainwater and health risks. Eight studies were identified linking RWH to occurrences of disease causing pathogens including Clostridium botulinum, Campylobacter species, Salmonella species and Legionella pneumophila. Further to this, Ward (2010) summarised fourteen studies between 2006 and 2010 that examined microbial and physicochemical harvested rainwater quality in developed countries and identified similar findings, though it was noted that small scale monitoring studies were limited for the UK context (Ward et al., 2010). Finally, de Kwaadsteniet et al (2013) summarised 38 studies between 1985 and 2012 and reinforced the findings of previous studies asserting that microbial indicators such as total coliforms and Enterococci and pathogens such as E. coli, Aeromonas spp., Campylobacter spp., Salmonella spp. and Giardia spp., as well as chemical contaminants, were indeed associated with RWH systems. They further asserted that longitudinal studies across different seasons were required to assess risk and determine requirements for treatment measures.

As well as research with harvested rainwater quality as its focus, studies have also been undertaken to assess and reduce health risks and examine measures to improve harvested water quality. For example, by undertaking good system design, installation and maintenance practices, risks can be minimized by promoting processes of flocculation and settling of physical, chemical and microbiological constituents within the RWH tank, eliminating daylight, keeping pipe runs as short as possible, cleaning catchment surfaces, prohibiting use of certain materials and installing filters (Konig, 2001; Coombes et al., 2005). However, where buildings are not designed with RWH systems in mind from the outset or RWH systems are poorly designed and managed, they may pose health risks (Ward et al., 2010; BSI, 2013). Concern regarding harvested rainwater quality and contact with end users (or accidental ingestion), for example by aerosols from toilet flushing, is regarded as one of a number of barriers to RWH in many countries, including in the UK (Fewtrell et al., 2008).

To quantify risk to health the Health Impact Assessment (HIA) approach, incorporating a Quantitative Microbial Risk Assessment (QMRA), can be used, which estimates positive/negative, intended/unintended, direct/indirect and single, multiple or cumulative health impacts. The QMRA is used to produce a 'disability affected life year' ('DALY') score summarising the health impact from the quantified organism. In relation to the DALY from exposure through utilisation of RWH, similar findings were observed by Fewtrell and Kay (2007b) and Ward (2010) indicating a marginally higher DALY score than from being struck by lightning $\left(1.8 \times 10^{-5}\right.$ for Enterococcus faecalis, $4.6 \times 10^{-5}$ for Campylobacter spp. and $2.1 \times 10^{-6}$ for lightning, respectively). Ahmed et al (2010), however, estimated a much higher impact (1.2-1.6 $\times 10^{-1}$ for salmonellosis and giardiasis, respectively), though noted their assumptions 
over-estimated the risk of infection. Fewtrell and Kay (2008) highlight that the designation of an 'acceptable' DALY (i.e. a tolerable health impact) is entirely political.

To reduce these impacts and risks and overcome ongoing concerns, research on POU treatment, including simple filtration or UV disinfection, is ongoing. Jordan et al (2008), in a US-based study of two experimental RWH systems with first flush diverters, tested two off the shelf POU devices in what they asserted to be the first study to evaluate such devices. The devices performed well for coliforms, but the harvested rainwater tested negative for both E. coli and Enterococci and therefore a spike test was performed to investigate microbial removal efficiency. After filtration $E$. coli was reduced only by $39 \%$ and after UV disinfection there was a substantial 6 log reduction, however heterotrophic plate count (HPC) did not reduce significantly. This was potentially due to biofilm regrowth at various locations throughout the POU device, necessitating recommendations on monitoring and maintenance as a priority for such equipment (Jordan et al., 2008).

De Kwaadsteniet et al (2013) undertook a thorough review of various POU devices (for example slow sand filters, granular-activated carbon filters, nanofiber filters, chlorination, vetiver grass, solar irradiation/pasteurization, ozone and silver ionization), but highlighted that research on their efficiency, durability and cost-effectiveness was limited. One device was identified that used a hybrid metal membrane-ozone generator, which effectively reduced microbial and particulate pollutants. However, it was disregarded for application in isolated rural communities in developing countries due to membrane blockage during continuous usage and the requirement for a constant source of electricity for the ozone generator. Building on this review, Dobrowsky et al (2015a, b) examined the efficacy of POU devices using solar and microfiltration processes and focused on two devices using a polyvinyl alcohol (PVA) nanofiber membrane/activated carbon column and closed-couple solar pasteurization, respectively. Tested on two experimental rainwater harvesting tanks, determinands monitored included heterotrophic bacteria (also known as heterotrophic plate counts (HPC) or Total Viable Counts (TVC), E. coli, total coliforms and adenoviruses. For the PVA POU device, results concluded that although $3 \mathrm{~L}$ of potable water with acceptable indicator organism levels could be produced, polymerase chain reaction (PCR) assays (to identify if organisms are present in a potentially viable but nonculturable state) revealed that adenovirus and bacteria including Klebsiella spp., Legionella spp., Pseudomonas spp., and Yersinia spp. were not successfully eliminated. The solar pasteurization POU device treated some cations to within guide drinking water guidelines with the exception of iron, aluminium, lead and nickel and indicator bacteria (TVC, E. coli and total coliforms) to below the detection limit for temperatures of $72^{\circ} \mathrm{C}$ and above. However, as in the previous study, Yersinia spp., Legionella spp. and Pseudomonas spp. were detected above $72^{\circ} \mathrm{C}$, though the viability of the bacteria was not ascertained.

As noted by de Kwaadsteniet et al (2013), RWH POU treatment devices incorporating ozonation have received limited attention in the literature to date, primarily due to their reduced efficacy for poor, rural communities. However, as RWH systems have become more common in urban locations in developed countries (Melville-Shreeve et al., 2015) where there are significant concerns over health risk (Fewtrell et al, 2008), reconsideration of the efficacy of such devices is warranted. To contribute to this area of research, this paper empirically examines the efficacy of a POU treatment device utilising filtration, UV and ozonation, across three international field trials. The paper proceeds as follows. The following Method section briefly summarises the main features of the patented 'RainSafe ${ }^{T M}$ ' point-of-use (RSPOU) device, the characteristics of the three trial locations and the water quality sampling and testing regime undertaken. The Results and Discussion section presents the main findings and recontextualises them in relation to the literature previously discussed. A final conclusion section reiterates the main themes of the paper. 


\section{Methods}

The methodological phases of the study consisted of: (i) the identification and characterisation of a novel POU RWH treatment device, the RSPOU; (ii) identification and characterisation of three international field trial sites with RWH systems representing different building scales; and (iii) sampling and testing harvested rainwater quality at the inlet, tank and outlet from the installed RSPOU devices across the three international field trial locations.

\subsection{A novel point-of-use treatment device}

The RSPOU device is a miniaturised treatment train (filtration, UV, ozone) that enables non-potable water (e.g. rainwater, well water) to be treated to meet potable (drinking, mains water) standards (e.g. World Health Organisation, 2008) and Drinking Water Directive (Council Directive 98/83/EC of 3 November 1998 on the quality of water intended for human consumption (Drinking Water Inspectorate, 2010). By connecting a RWH system (or other non-potable alternative water supply system) to a RSPOU device, the harvested water is treated enabling it to be consumed as drinking water or for similar end uses (bathing, showering, cooking). Where mains water availability or quality is low or properties are off-grid, the RWH-connected RSPOU device facilitates access to a readily available source of water (rainfall permitting). In order to trial the innovation in its first application to stimulate market replication, empirical testing of the water quality treatment performance of the POU device in relation to microbiological and physicochemical determinands was a priority.

The configuration of the RSPOU device is summarised in the flowchart provided in Figure 1. Harvested rainwater is processed, with a range of monitoring and metering devices, first through a $5 \mu \mathrm{m}$ inlet filter in preparation for treatment with UV light that attenuates biological contaminants. Ozone is generated and introduced into the 230 litre water holding tank - with the residual ozone providing sanitisation, replacing chlorine. UV-C disinfection is a reliable method used worldwide to treat drinking water. At the standard dose of $40 \mathrm{~mJ} / \mathrm{cm}^{2}$ UV-C deployed by drinking water treatment plants, parts of microbial cells that undergo UV-C disinfection may still be viable (Jungfer et al., 2007; Pablos et al., 2013). This resistance has also been shown following exposure to UV-C doses as high as $300 \mathrm{~mJ} \mathrm{~cm}$ (Zhang et al., 2015), and even after exposure to doses ten times greater than (Maganha de Almeida and Quilty, 2016). Consequently, the design of the RSPOU device allowed water to be disinfected by UV and then ozonated to prevent microbiological deterioration during storage.

When water is required for use, it is pumped through a carbon outlet filter. Ozone and carbon also improves the taste of the water, with carbon additionally converting any remaining ozone back to oxygen and removing flocculated particles prior to the water being circulated. The RSPOU device is simple to operate and maintain and is fitted with early warning and advanced safety and lock-out features in the event of component failure. As outlined in the RSPOU device Requirements Specification, source water should demonstrate the following characteristics:

- $\quad \geq 80 \%$ UV transmission;

- Turbidity $\leq 1$ NTU (nephlometric turbidity units);

- TOC (Total Organic Carbon) $\leq 4 \mathrm{mg} / \mathrm{l}$;

- De-chlorinated/Chlorine free water;

- Max. inlet pressure 6 bar \& Min. inlet pressure 2 bar;

- TSS (Total Suspended Solids) $\leq 1 \mathrm{mg} / \mathrm{L}$;

- Bromide $<5 \mu \mathrm{g} / \mathrm{l}$;

- $\mathrm{pH}$ 6.5-8. 
Where water does not fit within these requirements, pre-treatment may be required prior to the use of the RSPOU device. It is recommended the device be used with a properly installed RWH system, which includes a calmed inlet (prevents sediment agitation), a floating suction (sub-surface water withdrawal) and a debris filter or first-flush diverter on the inlet (leaf litter and other debris reduction). This should provide water comfortably within the required ranges of turbidity, UVT and TOC when collected from a suitable roofing surface. The inbound filters on the RSPOU device ensure that inbound water is free of particulate debris that could compromise the effectiveness of the UV treatment.

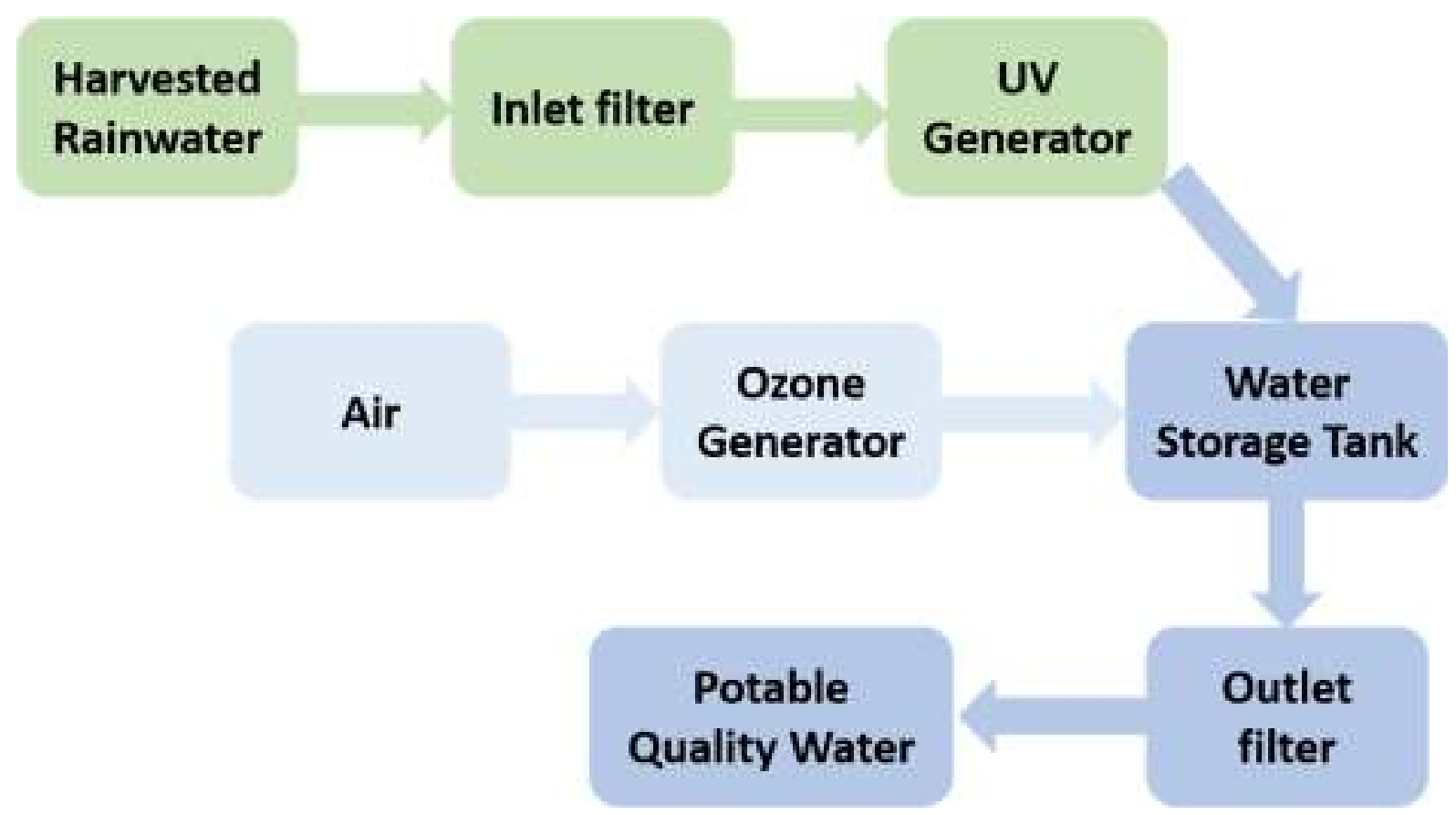

Figure 1. Configuration of the RainSafe ${ }^{\mathrm{TM}}$ point-of-use treatment device (RSPOU)

\subsection{International field trial locations}

RSPOU device field trials at different scales and in different international locations were undertaken to provide an analysis of the water quality treatment efficacy of the POU device. Data collected during the monitoring programme were analysed and the results and findings used to inform a failure modes and effects analysis (FMEA), though the latter is beyond the scope of this paper. The three international locations selected represented different contexts and scales, with England (an office building with cafe in Exeter) representing the large scale (EX01), Germany (an industrial unit in Scwerin) representing the medium scale (GLO1) and Ireland (three household-scale buildings) representing the small scale (TR01, SH01, BWM01). The locations of the devices are shown in Figure 2. The three locations also represented different annual average rainfalls $(784 \mathrm{~mm}, 614 \mathrm{~mm}$ and $733 \mathrm{~mm}$, respectively) and surroundings (peri-urban, industrial and urban, respectively), resulting in different harvested rainwater quality profiles and thus challenging the efficacy of the RSPOU in different ways. Five RSPOU devices with different configurations and characteristics were monitored across the three locations (England - EX01, Germany - GL01 and Ireland - TR01, SH01, BMW01). Table 1 summarises the site characteristics for the buildings and RWH systems for the three international field trial sites. Comparative experimental design was not possible, due to the timescale of the project, which necessitated using already identified sites, hence the focus of the research was to examine performance of the device in buildings of different scales in different contexts (i.e. different collection 
and demand characteristics). Laboratory testing of the device was undertaken at the headquarters of the parent company, but discussion of those results is beyond the remit of this paper, which is to focus on real-world performance.

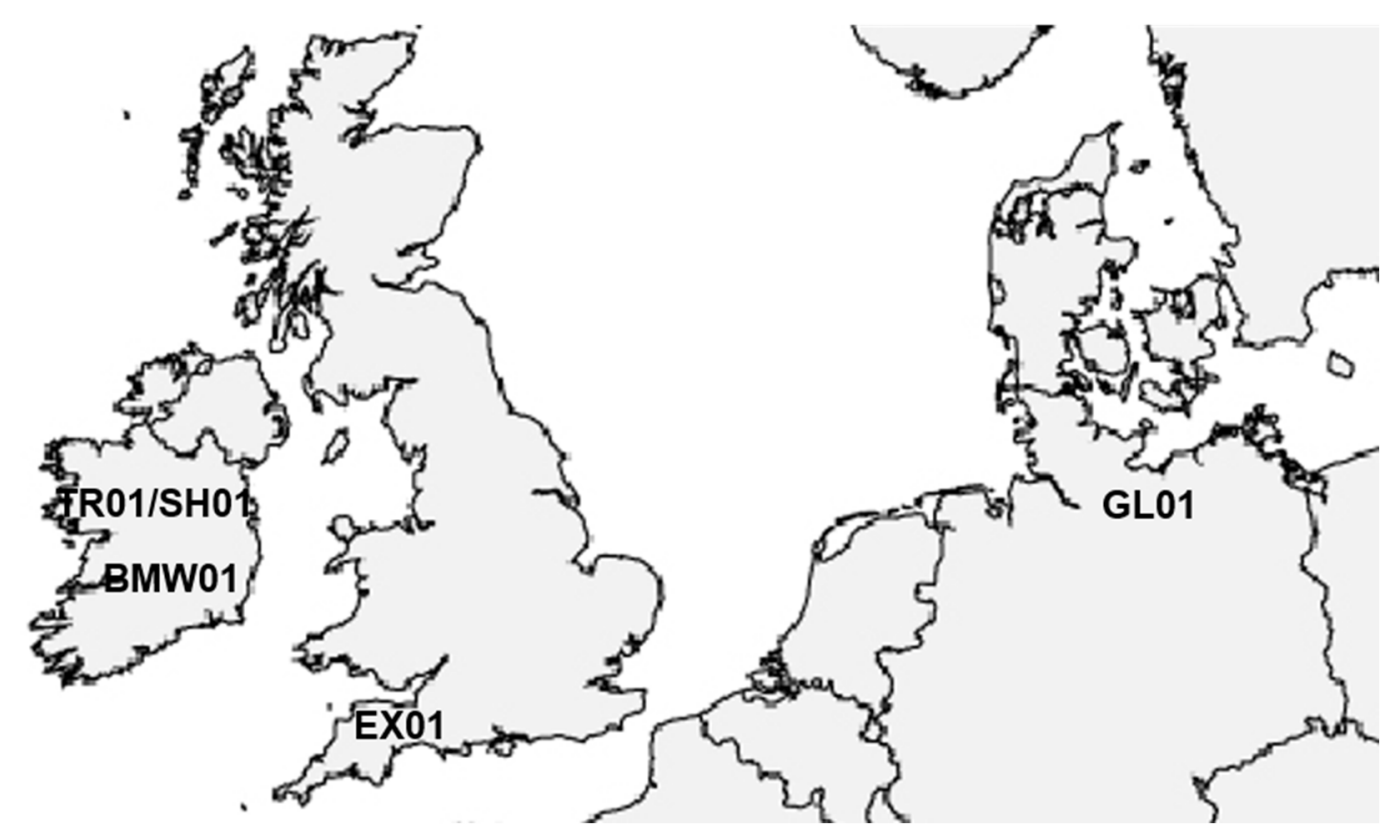

Figure 2. Locations of the five RSPOU devices

Table 1. Summary characteristics of the international RSPOU field trial sites

\begin{tabular}{cccccc}
\hline & England & \multicolumn{2}{c}{ Ireland (3 different sites) } & Germany \\
& $\begin{array}{c}\text { Exeter } \\
\text { (EX01) }\end{array}$ & $\begin{array}{c}\text { Trinity } \\
\text { (TR01) }\end{array}$ & $\begin{array}{c}\text { Shannon1 } \\
\text { (SH01) }\end{array}$ & $\begin{array}{c}\text { Ballymoney } \\
\text { (BMW01) }\end{array}$ & $\begin{array}{c}\text { Schwerin } \\
\text { (GL01) }\end{array}$ \\
\hline Type of building & $\begin{array}{c}\text { Non- } \\
\text { household } \\
\text { (offices) }\end{array}$ & $\begin{array}{c}\text { Non- } \\
\text { household } \\
\text { (section of } \\
\text { dental } \\
\text { hospital) }\end{array}$ & $\begin{array}{c}\text { Non- } \\
\text { household } \\
\text { (section of } \\
\text { offices) }\end{array}$ & Household & $\begin{array}{c}\text { Non-household } \\
\text { (manufacturing) }\end{array}$ \\
$\begin{array}{c}\text { Size (approx. } \\
\text { occupancy) }\end{array}$ & 250 & N/A & N/A & 2 & 11 \\
$\begin{array}{c}\text { Standard ave. } \\
\text { annual rainfall } \\
\text { (mm) }\end{array}$ & $784^{1}$ & $733^{2}$ & $976^{3}$ & $879^{4}$ & $614^{5}$ \\
$\begin{array}{c}\text { Catchment (roof) } \\
\text { area (m }{ }^{2} \text { ) }\end{array}$ & 1500 & 178 & 150 & 79 & 900 \\
& & & & & \\
\end{tabular}




\begin{tabular}{|c|c|c|c|c|c|}
\hline Roof type & $\begin{array}{l}\text { Flat, } \\
\text { smooth, } \\
\text { aluminium, } \\
\text { bitumen }\end{array}$ & $\begin{array}{l}\text { Flat, } \\
\text { smooth, } \\
\text { glass \& } \\
\text { unknown }\end{array}$ & $\begin{array}{l}\text { Pitched, } \\
\text { smooth, } \\
\text { tiled }\end{array}$ & $\begin{array}{l}\text { Pitched, } \\
\text { smooth, } \\
\text { slate }\end{array}$ & $\begin{array}{c}\text { Flat, smooth, } \\
\text { coated steel } \\
\text { plates }\end{array}$ \\
\hline $\begin{array}{l}\text { RWH storage tank } \\
\text { volume }\left(\mathrm{m}^{3}\right)\end{array}$ & 25 & 0.9 & 6 & 4.25 & 6.5 \\
\hline $\begin{array}{ll}\text { 1. } & \text { http://www.met } \\
\text { 2. } & \text { http://www.met. } \\
\text { 3. } & \text { http://www.met. } \\
\text { 4. } & \text { http://www.wex } \\
\text { 5. } & \text { http://en.climate }\end{array}$ & $\begin{array}{l}\text { ce.gov.uk/public/v } \\
\text { climate/dublinairp } \\
\text { climate/monthly-c } \\
\text { d.climatemps.com, } \\
\text { ta.org/location/12 }\end{array}$ & $\begin{array}{l}\text { her/climate/gc } \\
\text { asp } \\
\text { asp?Num=518 }\end{array}$ & & & \\
\hline
\end{tabular}

\subsection{Water quality sampling and testing regime}

Heterotrophic Plate Count (HPC) and Total Viable Count (TVC) are terms used interchangeably for the process of determining the number of viable organisms in a sample. In this research TVC was used throughout. The determination of TVC numbers was conducted according to microbiological methods recommended by the WHO (2003) drinking water guidelines. Samples of untreated and treated water were plated onto standard plate count agar using the spread-plate method. Each sample was plated in duplicates and incubated at two temperature: $22^{\circ} \mathrm{C}$ (for 72 hours) and at $37^{\circ} \mathrm{C}$ (for 48 hours) (WHO, 2003). The surviving cells were expressed as $\mathrm{CFU} \mathrm{mL}{ }^{-1}$. The temperature of $22^{\circ} \mathrm{C}$ targets growth of microorganisms ubiquitous to water and the environment, whereas growth of organisms at $37^{\circ} \mathrm{C}$ would potentially be linked to the presence of microorganisms originally growing in water frequented by warmed blooded animals i.e. faecal-polluted water.

By undertaking weekly sampling for TVC at both 22 and $37^{\circ} \mathrm{C}$ and monthly sampling for a range of other parameters, assessment was undertaken of whether the water produced by the RSPOU device was consistently of drinking water quality by comparing the results with the relevant standards for drinking water (WHO, 2008; Ward et al., 2010). Overall results (range, mean, standard deviation) from each field site installation are summarised in the tables in the Results and Discussion section along with relevant standard levels, including drinking water prescribed concentrations or values (PCVs).

Across all sites, samples were taken from the inlet to the RSPOU device from the RWH system (raw water), the RSPOU device tank (treated water) and the outlet from the RSPOU device into supply (treated water). The sampling period ran from February to December 2015 and samples were analysed for a range of parameters across the sites. For example, for the Exeter site seven microbiological and twenty physicochemical parameters were monitored (plus 63 pesticides and herbicides, tested in one sample). This extensive range of parameters was used, in order to examine their implications for both health and system function. Additionally, certain physicochemical parameters are known to interact with microbiological parameters and vice versa, therefore requiring as comprehensive an assessment as possible. Overall, a range of results were produced and analysed, for example for Exeter eight monthly sample suites and 26 weekly sample suites were generated and sampling was undertaken monthly for the three Irish sites throughout the full sampling period (there were only a limited number of occurrences within the sampling period when samples could not be taken, such as when systems were offline or sampling coordinators were away). Unfortunately, water quality sampling at the Schwerin site was restricted due to operational issues and delays and was only undertaken monthly for three months, those being February, June and October 2015. 
In relation to procedures, standard water quality sampling procedure is to flush a sampling point for a period proportional to the diameter and length of pipe prior to sampling to evaluate the quality of the water produced by the system and not of the standing water at the outlet. Due to the location of the sampling taps (inside buildings) this was not feasible (due to the length of hose/number of buckets that would be required to transport the flushed water). Instead, at least one litre of rainwater was drawn off immediately before samples were obtained. This procedure is in line with that used by Ahmed et al. (2008). Samples were kept in cool and dark conditions during transit and transported to the laboratory within a few hours of being obtained (or immediately in the case of SH01). The samples were pre-registered with and processed in commercial laboratories using standard methods (APHA, 2000).

\section{Results and Discussion}

To facilitate cross-site comparisons, the following sections discuss the results of the harvested rainwater quality testing regime for groups of determinands rather than per site. Comparisons to guidelines refer to those given by the WHO (2008) in relation to drinking water, unless otherwise specified.

\subsection{Organic Chemistry}

For the English device (EX01), single fungicide, herbicide, insecticide, organic solvents, pharmaceuticals, polycyclic aromatic hydrocarbons (PAHs) and trihalomethane tests were undertaken to determine a baseline to ascertain whether any exceedances of recommended levels were identified. All results were within the prescribed concentration or value (PCV) for drinking water. Levels of carbendazim and isoproturon in the pre-treated harvested rainwater were high $(0.278 \mu \mathrm{g} / \mathrm{l}$ and $0.052 \mu \mathrm{g} / \mathrm{l}$ against a standard level of $0.1 \mu \mathrm{g} / \mathrm{l}$, respectively), but still near to or within the PCV. However, levels post-treatment with the RSPOU device reduced to $<0.005 \mu \mathrm{g} / \mathrm{l}$. The potential source of the pesticides was the agricultural areas at the back of the car parks behind the office building containing the device, as such substances have not been used on the University campus in the last 5 years. The results could indicate a temporary wash-through effect from the adjacent soils, as the disappearance times of carbendazim may be in excess of a year (Johnson et al., 2012). Carbendazim at least is now a banned substance (from 2014). For the Irish and German RSPOU devices, fungicide, herbicide, insecticide, organic solvents, pharmaceuticals, PAHs and trihalomethane tests also were undertaken and all results were within the PCV for drinking water and no issues were identified. Ozone, as with all disinfectants, is associated with a risk of disinfectant by-products (DBPs) production. DBPs were examined as part of the trial. Bromate, formaldehyde and bromomethane were tested. Only bromate was detected above max allowable values and is discussed further in section 3.4.

\subsection{Total Viable Counts}

TVCs are the simplest indicator of the presence of microorganisms in a sample. These organisms may include bacteria, viruses, yeasts and mold. The count represents the number of colony forming units (cfu) per $\mathrm{ml}$ of sample. In Europe, the microbiological quality of water intended for human consumption is set by the Drinking Water Directive (DWI, 2010). The Drinking Water Directive sets values for indicators of faecal pollution, such as E. coli, Enterococci, Total Coliforms and Clostridium perfringens, but does not provide a value for TVC allowed for public drinking waters. However, the Drinking Water Directive does state that low numbers and no-abnormal changes should occur. There is no official guidance either in the UK or Europe to determine when an abnormal change occurs. The UK Water Supply (Water Quality) Regulations require colony count testing on water taken from public drinking water supplies, private supplies and bottled waters (DWI, 2010). For public water supplies no 
value for TVC is set, but the regulations state that there should be 'no abnormal change' (i.e. measurements should not show sudden or unexpected increases as well as no significant rising over time) and the Health and Safety Executive (2011) recommendation also supports the view of assessing 'no abnormal change'.

Figure 3 summarises all the TVC data collected for the inlet, tank and outlet for the English RSPOU device - values shown are transposed using the log function. On several occasions outlet TVC values were high compared with guideline levels for RWH use in spray applications, but acceptable when compared with non-spray applications, as indicated for example by the British Standard for Rainwater harvesting ( $<10$ and $<1000 \mathrm{cfu} / 100 \mathrm{ml}$, respectively (BSI, 2013)). Table 2 summarises the range, mean and standard deviation statistics for TVCs. The ranges and means shown in Table 2 show that although TVC values in inlet water can be high, they were substantially lower post-treatment in the tank, but began to increase again in some cases at the outlet. This was also observed by Jordan et al (2008) and is suggestive of small amounts of cfu-related biofilm regrowth in the post-treatment parts of the RSPOU device, which can be addressed through monitoring and maintenance.

As shown in Table 3, for the German device, the February TVC results were high at the outlet (despite levels being acceptable in the tank). The RSPOU device was installed during this month and performance was acclimatising to the site, which is the most probable cause of the levels, as levels in June and October were acceptable.

Table 4 summarises the range, mean and standard deviation for TVCs at the Irish sites. As also observed for the English site, on several occasions outlet TVC values were high. As previously discussed, this could indicate that a very small amount of cfu may be deposited (or perhaps be present in a biofilm) in the post-treatment parts of the RSPOU device and occasionally experience regrowth.

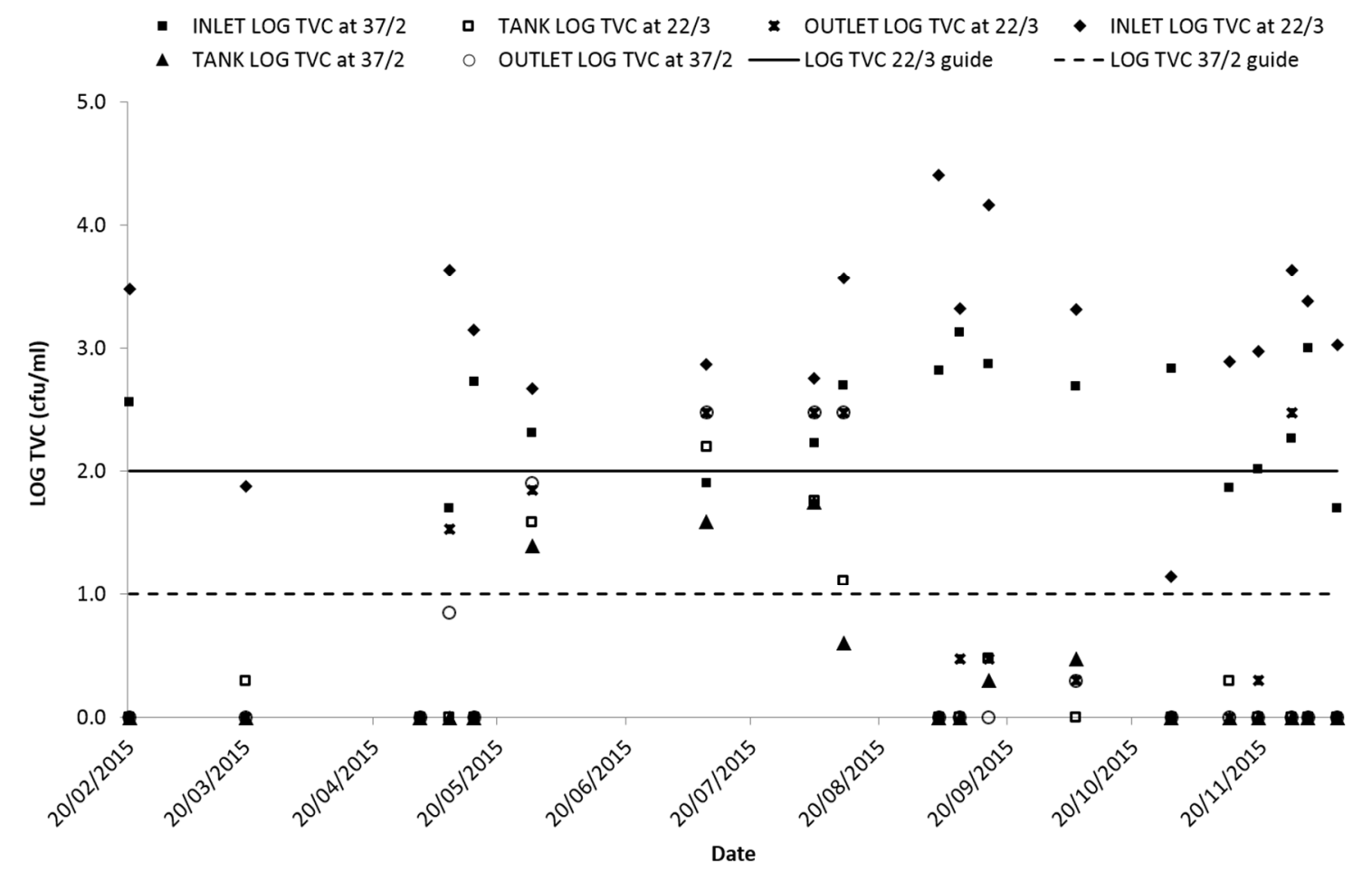

Figure 3. Total Viable Counts for the English (EX01) field trial site for the period February to December 2015 
Table 2. Summary of basic statistics for TVC results for the English (EX01) field trial site

\begin{tabular}{|c|c|c|c|c|c|c|}
\hline & \multicolumn{3}{|c|}{ TVC $22^{\circ} \mathrm{C}(\mathrm{cfu} / \mathrm{ml})$} & \multicolumn{3}{|c|}{ TVC $37^{\circ} \mathrm{C}(\mathrm{cfu} / \mathrm{ml})$} \\
\hline & Inlet & Tank & Outlet & Inlet & Tank & Outlet \\
\hline Range & $1-25600$ & $0-157$ & $0-300$ & $0-1350$ & $0-56$ & $0-300$ \\
\hline Mean & 3581 & 16 & 73 & 381 & 8 & 55 \\
\hline St & 6256 & 40 & 126 & 377 & 16 & 114 \\
\hline Dev. & & & & & & \\
\hline
\end{tabular}


Table 3. Summary of basic statistics for results for the German (GL01) field trial site (grey shaded cells indicate breach of the PCV)

\begin{tabular}{|c|c|c|c|c|c|c|c|c|c|c|c|c|c|}
\hline & PCV & $\begin{array}{l}\text { Inlet } \\
\text { Min }\end{array}$ & $\begin{array}{l}\text { Inlet } \\
\text { Max }\end{array}$ & $\begin{array}{l}\text { Inlet } \\
\text { Mean }\end{array}$ & $\begin{array}{c}\text { Inlet St } \\
\text { Dev. }\end{array}$ & $\begin{array}{l}\text { Tank } \\
\text { Min }\end{array}$ & $\begin{array}{l}\text { Tank } \\
\text { Max }\end{array}$ & $\begin{array}{c}\text { Tank } \\
\text { Mean } \\
\end{array}$ & $\begin{array}{c}\text { Tank St } \\
\text { Dev. }\end{array}$ & $\begin{array}{c}\text { Outlet } \\
\text { Min }\end{array}$ & $\begin{array}{c}\text { Outlet } \\
\text { Max }\end{array}$ & $\begin{array}{l}\text { Outlet } \\
\text { Mean }\end{array}$ & $\begin{array}{l}\text { Outlet } \\
\text { St Dev. }\end{array}$ \\
\hline Ammonium (mg/l) & 0.5 & 0.12 & 0.17 & 0.15 & 0.04 & 0.14 & 0.19 & 0.17 & 0.04 & 0.13 & 0.17 & 0.15 & 0.03 \\
\hline Conductivity ( $\mu \mathrm{s} / \mathrm{cm}-1)$ & 2500 & 33 & 117 & 66 & 45 & 34 & 90 & 58 & 29 & 36 & 85 & 57 & 25 \\
\hline Colour (mg/l) & none & $<0.2$ & $<0.2$ & $<0.2$ & $<0.2$ & $<0.2$ & $<0.2$ & $<0.2$ & $<0.2$ & $<0.2$ & N/A & $\mathrm{N} / \mathrm{A}$ & $\mathrm{N} / \mathrm{A}$ \\
\hline Turbidity (NTU) & $<1$ & 0.72 & 3.20 & 1.56 & 1.42 & 0.36 & 2.40 & 1.10 & 1.13 & 0.31 & 0.34 & 0.32 & 0.02 \\
\hline Iron $(\mu \mathrm{g} / \mathrm{I})$ & 200 & 0 & 100 & 43 & 51 & 0 & 110 & 47 & 57 & 0 & 40 & 20 & 20 \\
\hline Lead $(\mu \mathrm{g} / \mathrm{I})$ & 10 & $<3$ & $<3$ & $<3$ & $<3$ & $<0.003$ & $<3$ & $<3$ & $<3$ & $<3$ & $<3$ & $<3$ & $<3$ \\
\hline Cadmium ( $\mu \mathrm{g} / \mathrm{l})$ & 5 & $<0.5$ & $<0.5$ & $<0.5$ & $<0.5$ & $<0.0005$ & $<0.5$ & $<0.5$ & $<0.5$ & $<0.5$ & $<0.5$ & $<0.5$ & $<0.5$ \\
\hline Chlorine (mg/l) & 250 (chloride) & 1.47 & 5.04 & 2.91 & 1.88 & 1.52 & 5.07 & 2.92 & 1.89 & 1.52 & 5.19 & 2.97 & 2 \\
\hline Copper (mg/l) & 2 & $<0.01$ & $<0.01$ & $\mathrm{~N} / \mathrm{A}$ & $\mathrm{N} / \mathrm{A}$ & 0.02 & 0.02 & 0.02 & $\mathrm{~N} / \mathrm{A}$ & $<0.01$ & 0.02 & 0 & 0 \\
\hline Chromium ( $\mu \mathrm{g} / \mathrm{l})$ & 50 & $<0.005$ & $<5$ & $\mathrm{~N} / \mathrm{A}$ & $\mathrm{N} / \mathrm{A}$ & $<0.005$ & $<5$ & N/A & N/A & $<0.005$ & $<5$ & $\mathrm{~N} / \mathrm{A}$ & $\mathrm{N} / \mathrm{A}$ \\
\hline Bromate $(\mu \mathrm{g} / \mathrm{l})$ & 10 & $<0.006$ & $<6$ & $\mathrm{~N} / \mathrm{A}$ & $\mathrm{N} / \mathrm{A}$ & $<0.006$ & $<6$ & $\mathrm{~N} / \mathrm{A}$ & N/A & $<0.006$ & $<6$ & $\mathrm{~N} / \mathrm{A}$ & $\mathrm{N} / \mathrm{A}$ \\
\hline Manganese $(\mu \mathrm{g} / \mathrm{l})$ & 50 & $<5$ & 6.0 & 3.00 & 4.24 & 0.01 & 6.0 & 3.0 & 4.2 & $<5$ & 5.0 & 3 & 4 \\
\hline Arsenic ( $\mu \mathrm{g} / \mathrm{l})$ & 10 & $<2$ & $<2$ & N/A & $\mathrm{N} / \mathrm{A}$ & $<0.002$ & $<2$ & N/A & $\mathrm{N} / \mathrm{A}$ & $<2$ & $<2$ & $\mathrm{~N} / \mathrm{A}$ & $\mathrm{N} / \mathrm{A}$ \\
\hline Aluminium $(\mu \mathrm{g} / \mathrm{l})$ & 200 & $<20$ & 70 & $\mathrm{~N} / \mathrm{A}$ & $\mathrm{N} / \mathrm{A}$ & $<0.02$ & 100 & $\mathrm{~N} / \mathrm{A}$ & $\mathrm{N} / \mathrm{A}$ & 17 & 30 & 24 & 9 \\
\hline Nickel ( $\mu \mathrm{g} / \mathrm{l})$ & 20 & $<5$ & $<5$ & $\mathrm{~N} / \mathrm{A}$ & $\mathrm{N} / \mathrm{A}$ & $<0.005$ & $<5$ & $\mathrm{~N} / \mathrm{A}$ & $\mathrm{N} / \mathrm{A}$ & $<5$ & $<5$ & $\mathrm{~N} / \mathrm{A}$ & $\mathrm{N} / \mathrm{A}$ \\
\hline Magnesium & & $<0.3$ & 0.48 & N/A & $\mathrm{N} / \mathrm{A}$ & $<0.3$ & 0.40 & N/A & $\mathrm{N} / \mathrm{A}$ & $<0.3$ & 0.48 & $\mathrm{~N} / \mathrm{A}$ & $\mathrm{N} / \mathrm{A}$ \\
\hline nitrate $(\mathrm{mg} / \mathrm{l})$ & 50 & 3.96 & 4.59 & 4.19 & 0.35 & 4.83 & 6.90 & 6.06 & 1.09 & 3.90 & 6.73 & 5.18 & 1.43 \\
\hline nitrite $(\mathrm{mg} / \mathrm{l})$ & 0.5 & 0.01 & 0.07 & 0.04 & 0.04 & $<0.1$ & $<0.1$ & $\mathrm{~N} / \mathrm{A}$ & $\mathrm{N} / \mathrm{A}$ & $<0.1$ & $<0.1$ & $\mathrm{~N} / \mathrm{A}$ & $\mathrm{N} / \mathrm{A}$ \\
\hline UVT ( $\mu \mathrm{g} / \mathrm{l})$ & none & $\mathrm{N} / \mathrm{A}$ & $\mathrm{N} / \mathrm{A}$ & N/A & N/A & 92 & 92 & 92 & $\mathrm{~N} / \mathrm{A}$ & $\mathrm{N} / \mathrm{A}$ & $\mathrm{N} / \mathrm{A}$ & $\mathrm{N} / \mathrm{A}$ & $\mathrm{N} / \mathrm{A}$ \\
\hline TOC (mg/l) & no abn change & 1.00 & 1.40 & 1.17 & 0.21 & 0.90 & 1.20 & 1.07 & 0.15 & 0.80 & 1.10 & 1.00 & 0 \\
\hline pH (pH units) & $\geq 6,5$ and $\leq 9,5$ & 6.77 & 7.02 & 6.90 & 0.13 & 6.76 & 7.01 & 6.92 & 0.14 & 6.93 & 7.37 & 7.10 & 0 \\
\hline TVC 22 (per ml) & & 83 & $>300$ & N/A & N/A & 0 & 2 & 1 & 1 & 0 & 84 & 28 & 48 \\
\hline TVC 37 (per ml) & & 57 & 92 & 73 & 18 & 0 & 0 & 0 & 0 & 0 & 94 & 31 & 54 \\
\hline Coliforms (per $100 \mathrm{ml}$ ) & 0 & 0 & 600 & 300 & 424 & 0 & 0 & 0 & 0 & 0 & 0 & 0 & 0 \\
\hline E. coli (per $100 \mathrm{ml}$ ) & 0 & 0 & 2 & 1 & 1 & 0 & 0 & 0 & 0 & 0 & 0 & 0 & 0 \\
\hline Pseudomonas (per $100 \mathrm{ml}$ ) & N/A & 0 & 0 & 0 & 0 & 0 & 0 & 0 & 0 & 0 & 0 & 0 & 0 \\
\hline Enterococci (per $100 \mathrm{ml}$ ) & 0 & 0 & 9 & 3 & 5 & 0 & 0 & 0 & 0 & 0 & 0 & 0 & 0 \\
\hline Legionella (per $100 \mathrm{ml}$ ) & 0 & 0 & 1000 & 333 & 577 & 0 & 0 & 0 & 0 & 0 & 0 & 0 & 0 \\
\hline
\end{tabular}


Table 4. Summary of basic statistics for TVC results for the Irish field trial sites

\begin{tabular}{llcccccc}
\hline & & \multicolumn{3}{c}{ TVC $^{\circ}{ }^{\circ} \mathrm{C}$ (CFU/mI) } & \multicolumn{3}{c}{ TVC $37^{\circ} \mathrm{C}$ (CFU/ml) } \\
Site & Stat. & Inlet & Tank & Outlet & Inlet & Tank & Outlet \\
\hline Trinity & Range & $264-$ & $<1-2$ & $<1-500$ & $20-$ & $<1-8$ & $<1-370$ \\
(TR01) & & 18800 & & & 2500 & & \\
& Mean & 4481.6 & 1.5 & 149.13 & 913.2 & 3.33 & 53.38 \\
& St Dev. & 5962.95 & 0.71 & 157.54 & 877.23 & 4.04 & 128.11 \\
Shannon1 & Range & $56-298$ & $<1-126$ & $<1-$ & $<1-360$ & $<1-102$ & $<1-400$ \\
& & & & 1910 & & & \\
(SH01) & Mean & 154.4 & 31 & 352.71 & 96 & 39 & 115.33 \\
& St Dev. & 101.22 & 53.62 & 692.03 & 107.4 & 54.95 & 157.91 \\
Ballymoney & Range & $44-$ & $<1-$ & $<1-820$ & $51-$ & $<1-$ & $<1-800$ \\
(BWM01) & & 64000 & 5920 & & 12000 & 10000 & \\
& Mean & 10833.3 & 1404.8 & 376.86 & 2386.1 & 2407.83 & 265.63 \\
& St Dev. & 20295.67 & 2552.35 & 285.61 & 3876.69 & 4079.85 & 294.05 \\
\hline
\end{tabular}

\subsection{Coliforms, E. coli, Enterococci, P. aeruginosa and Legionella ('objectionable organisms')}

Results for other microbiological parameters for the English device (EX01) are summarised in Table 5. The ranges, means and standard deviations provide a basic statistical analysis of the results. Whilst levels, particularly of coliforms and enterococci, were high (above the PCV) in the inlet samples, the levels in the tank and outlet i.e. post-treatment with the RSPOU device were always zero. Additionally, whilst presumptive Pseudomonas aeruginosa levels were occasionally high in the inlet water, this did not necessarily lead to an increase in the confirmed levels in the outlet water. Despite some high results for TVCs and other microbiological indicators, a spot test for Legionella pneumophila and other Legionella species on 23-07-2015 returned a zero (not detected) result for inlet, tank and outlet.

These results were mirrored for the German site (GL01, Table 3), where levels of coliforms were high (above the PCV) in the inlet samples, but always zero in the tank and outlet i.e. post-treatment with the RSPOU device. Additionally, Pseudomonas aeruginosa levels were consistently zero. Tests for Legionella species showed one high level at the inlet, but that was reduced to zero at the outlet. As with the English site, despite high TVC results the other tests indicate that full pathogen removal is achievable when using the RSPOU device with an appropriate quality of source water.

Table 6 summarises the results for the Irish sites. Despite the high results for TVCs, the values of other microorganisms post-treatment for the tank and outlet are below the detection limit for the majority of the samples. Only for $P$. aeruginosa on one occasion for the site in Trinity (Dublin, TR01) (27/08/15) and Shannon (Dublin, SH01) (29/10/15) were levels greater than zero (3 cfu/100 ml). There is no PCV for $P$. aeruginosa, though the Uk's National Health Service (NHS, 2012, Table 1) suggests $<10$ is acceptable depending on the risk ascertained through a Water Safety Plan. In the USA (MDH, 2011), $500 \mathrm{cfu} / 100 \mathrm{ml}$ is presented as an acceptable level.

Consequently, over all, the samples comply with drinking water levels, though consideration of additional treatment processes could be given to address residual $P$. aeruginosa. In summary, whilst the microbiological results highlight there were incidences where the TVC values were high at the inlet and in some cases greater than 10 but less than 1000 at the tank and outlet, in general, this did not result in a corresponding rise in other objectionable organisms at the outlet. This indicates that full pathogen removal is achievable when using the RSPOU device with an appropriate quality of source water and the combined efficacy of UV and ozone disinfection ensures that drinking water guidelines 
are met. The remaining TVCs may result from residual cfu being present post-treatment, warranting investigation of potential interventions that could prevent such re-growth or biofilm formation, as a precautionary measure. Recent work has identified that silver-ion disinfection could be useful for such purposes within systems aiming to treat harvested rainwater to potable standards (Adler et al., 2013).

Table 5. Summary of Coliform, E. coli, Enterococci and P. aeruginosa results for the English site (EX01)

\begin{tabular}{|c|c|c|c|c|c|c|c|c|c|c|}
\hline & \multirow[b]{2}{*}{ PCV } & \multicolumn{3}{|c|}{$\begin{array}{l}\text { Inlet (CFU or } \\
\text { MPN/ } 100 \mathrm{ml} \text { ) }\end{array}$} & \multicolumn{3}{|c|}{$\begin{array}{l}\text { Tank (CFU or } \\
\text { MPN/ } 100 \mathrm{ml} \text { ) }\end{array}$} & \multicolumn{3}{|c|}{$\begin{array}{l}\text { Outlet (CFU or } \\
\text { MPN/ } 100 \mathrm{ml} \text { ) }\end{array}$} \\
\hline & & Range & Mean & $\begin{array}{l}\text { Std. } \\
\text { Dev. }\end{array}$ & Range & Mean & $\begin{array}{l}\text { Std. } \\
\text { Dev. }\end{array}$ & Range & Mean & $\begin{array}{l}\text { Std. } \\
\text { Dev. }\end{array}$ \\
\hline Coliform & 0 & $0-510$ & 185 & 203 & $\mathrm{~N} / \mathrm{A}$ & 0 & $\mathrm{~N} / \mathrm{A}$ & $\mathrm{N} / \mathrm{A}$ & 0 & $\mathrm{~N} / \mathrm{A}$ \\
\hline E. coli & 0 & $0-210$ & 57 & 75 & $\mathrm{~N} / \mathrm{A}$ & 0 & $\mathrm{~N} / \mathrm{A}$ & N/A & 0 & N/A \\
\hline Enterococci & 0 & $0-900$ & 229 & 309 & $\mathrm{~N} / \mathrm{A}$ & 0 & N/A & N/A & 0 & N/A \\
\hline $\begin{array}{l}P . \\
\text { aeruginosa } \\
\text { confirmed* }\end{array}$ & N/A & $\begin{array}{l}0-1 \\
(0- \\
1000)\end{array}$ & $\begin{array}{l}\text { N/A } \\
(264)\end{array}$ & $\begin{array}{l}\text { N/A } \\
(352)\end{array}$ & $\begin{array}{l}0 \\
(0- \\
110)\end{array}$ & $\begin{array}{l}\text { N/A } \\
\text { (18) }\end{array}$ & $\begin{array}{l}\text { N/A } \\
\text { (41) }\end{array}$ & $\begin{array}{l}0 \\
(0- \\
1000)\end{array}$ & $\begin{array}{l}\text { N/A } \\
(287)\end{array}$ & $\begin{array}{l}\text { N/A } \\
\text { (487) }\end{array}$ \\
\hline
\end{tabular}

* values in parenthesis are presumptive

**Coliforms/E. coli: MPN

*** Enteroccoci , P. aeruginosa: CFU

\subsection{Physico-chemical parameters}

A summary of the physico-chemical results for the English (EX01) device is provided in Table 7, with breaches highlighted with grey shading. The acceptable range for $\mathrm{pH}$ in drinking water is 6.5-9.5 and the $\mathrm{pH}$ range for the English system (across the inlet, tank and outlet) was 6.4-7.2 with a mean of 6.8 i.e. the measured range was almost always within the standard range. Ammonium (NH4) exceeded the PCV on one occasion for the outlet (0.51 on $01-05-15)$, but only to a very minor extent $(0.1 \mathrm{mg} / \mathrm{l})$. The only other parameter returning a value higher than the PCV was lead (Pb; $10 \mu \mathrm{g} / \mathrm{l})$, which twice showed levels above the drinking standard in both the inlet $(11.3 \mu \mathrm{g} / \mathrm{l}$ on $23-07-15 ; 21.9 \mu \mathrm{g} / \mathrm{l}$ on 18 08-15) and outlet (27.4 $\mathrm{gg} / \mathrm{I}$ on $20-02-15 ; 18.1 \mu \mathrm{g} / \mathrm{I} / \mathrm{I}$ on $15-12-15)$. From an examination of these data points in relation to other parameters no correlations were observed and therefore the most likely explanation is the softness of the water. Ward et al. (2010) also observed lead levels in excess of drinking water guidelines when harvested rainwater from the office building RWH system was analysed, possibly due to coatings on external rainwater goods. Other possible explanations include the ozone acting as a coagulant for lead and an agglomeration came into suspension during the highlighted sampling occasions or the lead was bound to organic matter and was released when ozone processes were activated. Whilst this is of potential concern from a drinking water perspective, levels were below those expected if plumbosolvency of any lead fittings were occurring $(100 \mu \mathrm{g} / \mathrm{l}$; WHO, 2008) due to the low $\mathrm{pH}$ of the harvested rainwater. Potential implications of the lead results were considered in the previously mentioned FMEA, by highlighting the requirement for source water and treatment processes to be appropriately matched.

Copper $(\mathrm{Cu})$ levels were well below the drinking water standard, but on occasion they did approach levels observed to cause staining of sanitaryware $(1 \mathrm{mg} / \mathrm{l})(\mathrm{WHO}, 2008)$. The presence of copper is 
known to increase the corrosion of galvanized iron and steel fittings (and stain plumbing fixtures at iron levels greater than $300 \mu \mathrm{g} / \mathrm{l}$ (WHO, 2008). As limited amounts of these materials comprise the RSPOU device (and where they do there is limited contact with the water), this is unlikely to be of concern.

For the German (GLO1) device the results were within the acceptable pH range at the inlet, tank and outlet. As with TVCs in February, turbidity was higher than the PCV at the inlet and tank, but not the outlet, which is most likely attributable to the installation, as June and October levels were below the PCV in the inlet, tank and outlet. This highlights the requirement for a 'stabilisation period' to enable the performance of the RSPOU device to reach a suitable level. All other physico-chemical parameters were within permitted levels and therefore had no implications for potable consumption or system function.

The $\mathrm{pH}$ range across the three Irish systems (across the inlet, tank and outlet) was 4.91-8.1 with a mean of 6.8. SHO1 had a consistent pH of around 7.4, however, the other two sites experienced pH values below the lower acceptable range for drinking water (no values were observed above the maximum of the range, 9.5). For the Trinity (Dublin, TR01) device the $\mathrm{pH}$ dropped below 6.5 twice at the inlet, six times in the tank and three times at the outlet, but was never below 6.1 (tank). For the Ballymoney (County Wexford, Rep. of Ireland, BMW01), the pH dropped below 6.5 five times at the inlet, eight times in the tank and seven times at the outlet and the lowest recorded value was 4.9 (tank). The WHO (2008) advises that pH dominates the solubility and reaction rate of most metals involved in corrosion reactions, with a low $\mathrm{pH}$ being implicated in corrosion.

In relation to this, detailed examination of the results for metals was undertaken and it was observed that lead levels at Ballymoney (BMW01) exceeded the drinking water standard (10 $\mu \mathrm{g} / \mathrm{l})$ on all but one occasion for the inlet $(\min =9.4 \mu \mathrm{g} / \mathrm{l}, \max =40 \mu \mathrm{g} / \mathrm{l}$ ) and on half the sampling occasions for the outlet ( $\max =350 \mu \mathrm{g} / \mathrm{l}$ ). It is uncertain as to how higher levels occur at the outlet and therefore this issue could be investigated further. The occurrence may be attributable to ozone perhaps acting as a coagulant for lead with the agglomeration coming into suspension during a particular sampling occasion. As previously discussed, such lead levels in combination with the low $\mathrm{pH}$ of the water could affect the plumbosolvency of other metals (though this effect was not observed in the available data), as well as having drinking water implications.

This indicates that $\mathrm{pH}$ and lead may be a cause for concern at the Ballymoney (BMW01) site, reinforcing the need to appropriately consider pre-treatment of source water and maintenance of RWH equipment. Other breaches of drinking water standards included:

- Trinity (TR01):

- Inlet ammonium max of 0.4 (standard $=0.3 \mathrm{mg} / \mathrm{l}$ );

- Inlet turbidity max. of 2.0 (Irish standard = <1 NTU; UK = 4 NTU);

○ Inlet lead max. of $11.3 \mu \mathrm{g} / \mathrm{l}$ (exceeded by 1.3);

○ Inlet/outlet copper max. of 6.4 and $196 \mathrm{mg} / \mathrm{l}$, respectively (standard $=2 \mathrm{mg} / \mathrm{l}$ ).

- Shannon (SH01):

- Inlet/outlet copper max. of 6 and $303 \mathrm{mg} / \mathrm{l}$, respectively (standard = $2 \mathrm{mg} / \mathrm{l}$ );

○ Inlet, tank and outlet bromate max. of $17 \mu \mathrm{g} / \mathrm{l}, 48 \mu \mathrm{g} / \mathrm{l}$ and $46 \mu \mathrm{g} / \mathrm{l}$, respectively (standard = 10 $\mu \mathrm{g} / \mathrm{l})$;

- Inlet nitrate max. of $56.1 \mathrm{mg} / \mathrm{l}$ (exceeded by $6.1 \mathrm{mg} / \mathrm{l}$ );

- Ballymoney (BMW01): 
- Inlet and outlet ammonium max. of 0.8 and 0.54 , respectively (Irish standard $=0.3 \mathrm{mg} / \mathrm{l}$; UK standard $=0.5 \mathrm{mg} / \mathrm{l}$ )

$\circ$ Inlet, tank and outlet turbidity max. of 1.1, 9.9 and 4, respectively (standard $=<1$ NTU).

The majority of these breaches are most likely sporadic outliers that occur for no systematic reason, due to natural variation, as with drinking water produced and distributed via a centralised water system. Due to the extent of the breaches, particularly the ammonium results for Ballymoney (BMW01) and bromate results for Shannon (SH01), it could be concluded that these sources require pre-treatment before connection to a RSPOU device. Bromate is not normally found in water, but may be formed during ozonation when the bromide ion is present. Upon ozonation, conversion of bromide to bromate may be affected by natural organic matter, $\mathrm{pH}$, temperature and ozone characteristics, among other factors, but with bromide concentration and ozone dose being the best predictors of bromate formation (WHO, 2005). According to WHO (2005) it is unlikely that the observed levels would have health impacts, however the guidance reviews a range of studies and recommended the guideline value of $10 \mu \mathrm{g} / \mathrm{l}$ as it is associated with an upper-bound excess lifetime cancer risk of $5 \times 10^{-}$ 5 .

Over all, both the microbiological and physico-chemical results summarised in this study are in line with previous studies, although the microbiological efficiency of the RSPOU device exceeded that of the POU devices tested by Dobrowsky (2015a, b) for the determinands examined. Regarding palatability, there were no issues with taste or odour where the RSPOU device had been subject to an adequate stabilisation period. The results presented demonstrate that it is possible to alleviate health risks and impacts by treating harvested rainwater collected through a RWH system using the RSPOU device. This may be desirable if the water is to be used for potable end uses such as drinking and cooking or for end uses where the likelihood of ingestion or inhalation is high, such as bathing or showering. Whether or not the risk posed by usage in low exposure end uses such as toilet flushing, irrigation or vehicle washing warrants treatment to potable standard is a question for debate.

As established by Fewtrell et al. (2008) and Ward (2010) aerosols from toilet flushing yielded DALY scores within an acceptable screening level, but were slightly higher than from being struck by lightning. In the case of the latter, which relates to the same RWH system examined in this study, it might be sensible to utilise the POU device, as there is no first flush device and building design features were identified as having implications for harvested rainwater quality (Ward et al., 2010). Where utilised in appropriate contexts, the RSPOU device could help alleviate concerns regarding the quality of water produced by RWH systems, one of the main barriers to adoption in urban locations in developed countries. 
Table 6. Summary of Coliform, E. coli (MPN/100ml) and Enterococci and P. aeruginosa (CFU/100ml) results for the Irish sites

\begin{tabular}{|c|c|c|c|c|c|c|c|c|c|c|c|c|}
\hline Trinity (TR01) & $\begin{array}{l}\text { Inlet } \\
\text { Min }\end{array}$ & $\begin{array}{l}\text { Inlet } \\
\text { Max }\end{array}$ & Inlet Mean & Inlet St Dev & $\begin{array}{l}\text { Tank } \\
\text { Min }\end{array}$ & $\begin{array}{l}\text { Tank } \\
\text { Max }\end{array}$ & $\begin{array}{l}\text { Tank } \\
\text { Mean }\end{array}$ & $\begin{array}{c}\text { Tank St } \\
\text { Dev }\end{array}$ & $\begin{array}{c}\text { Outlet } \\
\text { Min }\end{array}$ & $\begin{array}{c}\text { Outlet } \\
\text { Max }\end{array}$ & $\begin{array}{l}\text { Outlet } \\
\text { Mean }\end{array}$ & $\begin{array}{l}\text { Outlet } \\
\text { St Dev }\end{array}$ \\
\hline Coliforms & $<1$ & 1300 & 455 & 540 & $<1$ & $<1$ & $<1$ & $<1$ & $<1$ & $<1$ & $<1$ & $<1$ \\
\hline E. coli & $<1$ & 613 & 109 & 206 & $<1$ & $<1$ & $<1$ & $<1$ & $<1$ & $<1$ & $<1$ & $<1$ \\
\hline Pseudomonas & $<1$ & 568 & 205 & 177 & $<1$ & $<1$ & $<1$ & $<1$ & $<1$ & 3 & N/A & N/A \\
\hline Enterococci & $<1$ & $>2419.6$ & 404.58 & 851.74 & $<1$ & 1 & $\mathrm{~N} / \mathrm{A}$ & N/A & $<1$ & $<1$ & $<1$ & $<1$ \\
\hline \multicolumn{13}{|l|}{$\underline{\text { Shannon1 (SH01) }}$} \\
\hline Coliforms & $<1$ & $>2419.6$ & 638.79 & 822.27 & $<1$ & 0 & 0 & 0 & $<1$ & $<1$ & 0 & 0 \\
\hline E. coli & $<1$ & 88.2 & 42.45 & 43.58 & $<1$ & 0 & 0 & 0 & $<1$ & $<1$ & 0 & 0 \\
\hline Pseudomonas & $<1$ & 95 & 27.75 & 35.54 & $<1$ & 0 & 0 & 0 & $<1$ & 3 & N/A & N/A \\
\hline $\begin{array}{l}\text { Enterococci } \\
\text { Ballvmoney }\end{array}$ & $<1$ & 613.1 & 81.54 & 200.85 & $<1$ & 0 & 0 & 0 & $<1$ & $<1$ & 0 & 0 \\
\hline (BMW01) & & & & & & & & & & & & \\
\hline Coliforms & $<1$ & $>2419.6$ & 496.7 & 710.27 & $<1$ & 0 & 0 & 0 & $<1$ & $<1$ & 0 & 0 \\
\hline E. coli & $<1$ & 547.5 & 115.51 & 199.91 & $<1$ & 0 & 0 & 0 & $<1$ & $<1$ & 0 & 0 \\
\hline Pseudomonas & $<1$ & 4950 & 757.11 & 1583.24 & $<1$ & 12 & $\mathrm{~N} / \mathrm{A}$ & N/A & $<1$ & $<1$ & 0 & 0 \\
\hline Enterococci & $<1$ & 866.4 & 251.78 & 344.60 & $<1$ & 0 & 0 & 0 & $<1$ & $<1$ & 0 & 0 \\
\hline
\end{tabular}

$* \mathrm{~N} / \mathrm{A}=$ not calculated due to number of data points 
Table 7. Summary of physico-chemical results for the English site (EX01) (grey shaded cells indicate breach of the PCV)

\begin{tabular}{|c|c|c|c|c|c|c|c|c|c|c|c|c|c|}
\hline Parameter & PCV & $\begin{array}{l}\text { Inlet } \\
\text { Min }\end{array}$ & $\begin{array}{l}\text { Inlet } \\
\text { Max }\end{array}$ & $\begin{array}{l}\text { Inlet } \\
\text { Mean }\end{array}$ & $\begin{array}{c}\text { Inlet St } \\
\text { Dev. }\end{array}$ & $\begin{array}{l}\text { Tank } \\
\text { Min }\end{array}$ & $\begin{array}{l}\text { Tank } \\
\text { Max }\end{array}$ & $\begin{array}{l}\text { Tank } \\
\text { Mean }\end{array}$ & $\begin{array}{c}\text { Tank } \\
\text { St Dev. }\end{array}$ & $\begin{array}{c}\text { Outlet } \\
\text { Min }\end{array}$ & $\begin{array}{l}\text { Outlet } \\
\text { Max }\end{array}$ & $\begin{array}{l}\text { Outlet } \\
\text { Mean }\end{array}$ & $\begin{array}{l}\text { Outlet } \\
\text { St Dev. }\end{array}$ \\
\hline & $6.5-$ & & & & & & & & & & & & \\
\hline $\mathrm{pH}$ in Water (pH units) & 9.5 & 6.40 & 7.20 & 6.74 & 0.30 & 6.40 & 7.00 & 6.68 & 0.20 & 6.40 & 7.20 & 6.76 & 0.25 \\
\hline Cond in Water $\mathrm{uS} / \mathrm{cm}$ & 2500 & 25.40 & 51.70 & 33.86 & 8.64 & 26.10 & 52.00 & 36.53 & 9.52 & 26.00 & 52.20 & 36.10 & 9.32 \\
\hline Colour as $\mathrm{Pt} / \mathrm{Co}(\mathrm{mg} / \mathrm{l})$ & 20 & 1.90 & 9.40 & 4.34 & 2.89 & 0.30 & 1.90 & 1.22 & 0.65 & 0.20 & 2.50 & 1.08 & 0.86 \\
\hline Turbidity (NTU) & 4 & 0.98 & 1.50 & 1.17 & 0.17 & 0.12 & 1.10 & 0.67 & 0.36 & 0.16 & 1.10 & 0.67 & 0.34 \\
\hline $\mathrm{TOC}(\mathrm{mg} / \mathrm{l})$ & / & 1.19 & 4.50 & 3.73 & 1.26 & 1.13 & 6.70 & 4.40 & 1.69 & 0.92 & 5.70 & 3.83 & 1.61 \\
\hline TON NO3 Water (mg/l) & / & 2.12 & 2.12 & 2.12 & N/A & 4.02 & 4.10 & 4.10 & 0.06 & 2.18 & 4.15 & 3.45 & 0.89 \\
\hline $\mathrm{NH} 4$ Tot Water $(\mathrm{mg} / \mathrm{l})$ & 0.5 & 0.04 & 0.40 & 0.18 & 0.17 & & & & & 0.04 & 0.51 & 0.23 & 0.22 \\
\hline NO3 NO3 Water Calc (mg/l) & 50 & 2.12 & 2.12 & 2.12 & N/A & 4.02 & 4.10 & 4.10 & 0.06 & 2.18 & 4.15 & 3.45 & 0.89 \\
\hline NO2 NO2 Water $(\mathrm{mg} / \mathrm{l})$ & 0.5 & $<0.01$ & 0.04 & 0.03 & 0.01 & $<0.01$ & $<0.01$ & N/A & N/A & $<0.01$ & $<0.01$ & N/A & N/A \\
\hline Mg Tot Water (mg/l) & / & 0.36 & 0.61 & 0.46 & 0.12 & & & & & 0.41 & 0.62 & 0.54 & 0.10 \\
\hline Al Tot Water ug/l & 200 & 15.50 & 51.10 & 30.29 & 12.81 & & & & & 11.20 & 43.30 & 25.58 & 12.12 \\
\hline Fe Tot Water ug/l & 200 & 8.74 & 94.80 & 34.21 & 30.99 & & & & & 7.85 & 51.90 & 25.27 & 19.61 \\
\hline Mn Tot Water ug/l & 50 & 2.10 & 22.40 & 8.35 & 7.89 & & & & & 2.24 & 20.70 & 9.27 & 7.58 \\
\hline Cu Tot Water ug/l & 2 & 0.18 & 0.87 & 0.40 & 0.29 & & & & & 0.17 & 0.60 & 0.34 & 0.17 \\
\hline $\mathrm{Pb}$ Tot Water ug/l & 10 & 1.03 & 21.90 & 6.28 & 7.76 & & & & & 0.64 & 27.40 & 8.64 & 10.23 \\
\hline Cd Tot Water ug/l & 5 & $<0.25$ & $<0.25$ & N/A & N/A & & & & & $<0.25$ & $<0.25$ & N/A & N/A \\
\hline Cr Tot Water ug/l & 50 & $<0.4$ & 0.48 & N/A & N/A & & & & & $<0.4$ & 0.44 & N/A & N/A \\
\hline $\mathrm{Ni}$ Tot Water ug/l & 20 & $<1$ & 2.48 & 1.75 & 1.03 & & & & & $<1$ & 1.56 & N/A & N/A \\
\hline As Tot Water ug/l & 10 & $<0.2$ & 0.29 & N/A & N/A & & & & & $<0.2$ & 0.28 & 0.26 & 0.04 \\
\hline Chlorine CALC (mg/l) & $250^{\mathrm{a}}$ & 0.00 & 0.06 & 0.03 & 0.02 & & & & & 0.00 & 0.06 & 0.03 & 0.02 \\
\hline Chlorine FREE by DPD & & & & & & & & & & & & & \\
\hline$(\mathrm{mg} / \mathrm{l})$ & $250^{\mathrm{a}}$ & 0.02 & 0.24 & 0.08 & 0.08 & & & & & 0.01 & 0.24 & 0.09 & 0.09 \\
\hline Chlorine TOT by DPD (mg/l) & $250^{\mathrm{a}}$ & 0.06 & 0.27 & 0.11 & 0.08 & & & & & 0.05 & 0.26 & 0.12 & 0.08 \\
\hline
\end{tabular}




\section{Conclusions}

The research presented in this paper comprehensively examined the longitudinal microbiological and physicochemical efficacy of the RSPOU device, which treats harvested rainwater collected from RWH systems using filtration, UV and ozonation. By undertaking regular water quality sampling for a range of determinands in systems representing small, medium and large scales, assessment was made as to whether the water produced by the RSPOU device across five experimental sites (in England, Ireland and Germany) was consistently of drinking water quality by comparing the results with the relevant standards for drinking water. With regard to organic chemistry, fungicide, herbicide, insecticide, organic solvents, pharmaceuticals, PAHs and trihalomethane levels across all of the sites tested proved unproblematic. Physico-chemically, the majority of the results were within the permitted values. There were some minor breaches relating to $\mathrm{pH}$, lead, bromate, ammonium, nitrate and copper, potentially due to floc disaggregation, some of which would have implications for drinking water. Use of the RSPOU device without pre-treatment at the sites from which these values were recorded should be reconsidered, in line with the recommendation that, where appropriate, additional pre-treatment units should be used prior to the RSPOU device.

Microbiologically, results showed that whilst TVC values in inlet water were high, they were substantially lower post-treatment in the tank and outlet and the majority were within suggested guidelines (no formal guideline exists). In a small number of samples a very small number of cfu may have been deposited (or perhaps be present in a biofilm) in the post-treatment parts of the RSPOU device equipment, which occasionally led to regrowth. However, results for other microbiological parameters, particularly coliforms and enterococci, showed that despite some high readings (above the PCV) in the inlet samples, the levels in the tank and outlet i.e. post-treatment with the RSPOU device were always zero. Additionally, $P$. aeruginosa levels were generally zero (CFU/100ml) after treatment, though residual values were noted on two occasions at one of the Irish sites. Legionella values at the outlet were always zero. Consequently, it can be concluded that although microbial indicator parameters may show non-zero values, full pathogen removal is achievable when using the RSPOU device with an appropriate quality of source water. Finally, a post-installation 'stabilisation period' is recommended to enable the performance of the RSPOU device to reach a suitable level before water is consumed. This was noted particularly in relation to stabilising palatability and future research on palatability through taste testing with different audiences is recommended due to the positive influence of ozone on palatability.

In conclusion, by treating harvested rainwater collected through a RWH system using the RSPOU device health risks and impacts can be alleviated. Consequently, despite being previously disregarded, POU devices incorporating filtration, UV and ozone warrant further attention as a technology to complement RWH where electricity is constant and to avoid excess energy consumption could be provided from renewable sources. For potable end-uses this is particularly relevant for urban locations in developed countries where such risks and impacts are one of the main barriers to adoption. For non-potable end-uses whether the addition of such a device to a RWH system is warranted, is a question still open for debate.

\section{Acknowledgements}

This research was funded by the European Commission's Eco-Innovation programme (ECO/12/332899) and supported by Ozone Industries Ireland Ltd, the University of Exeter, Flextronics International, Greenlife and Kiwa. 


\section{References}

ADLER, I., HUDSON-EDWARDS, K. A. and CAMPOS, L. C. (2013) Evaluation of a silver-ion based purification system for rainwater harvesting at a small-scale community level. Journal of Water Supply: Research and Technology-AQUA, 62 (8) 545-551; DOI: 10.2166/aqua.2013.049

AHMED, W., HUYGENS, F., GOONETILlEKE, A. \& GARDNER, T. (2008) Real-Time PCR Detection of Pathogenic Microorganisms in Roof-Harvested Rainwater of Southeast Queensland, Australia. Applied and Environmental Microbiology, 74 (17), 5490-5496.

AHMED, W., VIERITZ, A., GOONETILLEKE, A. \& GARDNER, T. (2010) Health Risk from the Use of RoofHarvested Rainwater in Southeast Queensland, Australia, as Potable or Nonpotable Water, Determined Using Quantitative Microbial Risk Assessment. Applied and Environmental Microbiology, 76, 7382-7391.

AHMED, W., GARDNER, T. \& TOZE, S. (2011) Microbiological Quality of Roof-Harvested Rainwater and Health Risks: A Review. Journal of Environmental Quality, 40, 13-21.

AMOS, C. C., RAHMAN, A. AND GATHENYA, J. M. (2016) Economic analysis and feasibility of rainwater harvesting systems in urban and peri-urban environments: a review of the global situation with a special focus on Australia and Kenya. Water, 8, 149, doi:10.3390/w8040149.

APHA (2000) Standard Methods for the Examination of Water and Wastewater. APHA, Washington.

BRITISH STANDARD INSTITUTE (2013) BS 8515:2013 Code of Practice for rainwater harvesting systems. $\mathrm{BSI}$, London.

COOMBES, P. J., DUNSTAN, H., SPINKS, A. T., EVANS, C. \& HARRISON, T. (2005) An overview of a decade of research into the quality of rainwater supplies collected from roofs. Proceedings of the 12th International Conference of the International Rainwater Catchment Systems Association. New Delhi, India.

CRC (2005) Public Health Aspects of Rainwater Tanks in Urban Australia. Cooperative Research Centre for Water Quality and Treatment, Occasional Paper 10. ISBN 1876616431.

DE KWAADSTENIET, M., DOBROWSKY, P.H., VAN DEVENTER, A., KHAN, W. AND CLOETE, T. E. (2013) Domestic rainwater harvesting: microbial and chemical water quality and point-of-use treatment systems. Water Air \& Soil Pollution, 224, 1629, DOI 10.1007/s11270-013-1629-7.

DOBROWSKY, P. H., CARSTENS, M., DE VILLIERS, J., CLOETE, T. E. \& KHAN, W. (2015a) Efficiency of a closed-coupled solar pasteurization system in treating roof harvested rainwater. Science of the Total Environment, 536, 206-214, DOI.org/10.1016/j.scitotenv.2015.06.126.

DOBROWSKY, P. H., LOMBARD, M., CLOETE, W. J., SAAYMAN, M., CLOTE, T. E., CARSTENS, M., KHAN, S. AND KHAN, W. (2015b) Efficiency of microfiltration systems for the removal of bacterial and viral contaminants from surface and rainwater. Water Air \& Soil Pollution, 226, 33, DOI 10.1007/s11270015-2317-6.

DRINKING WATER INSPECTORATE (2010) What are the drinking water standards? http://dwi.defra.gov.uk/consumers/advice-leaflets/standards.pdf Accessed 14-07-2015

FEWTRELL, L. \& KAY, D. (2007a) Microbial quality of rainwater supplies in developed countries - a review. Urban Water, 4 (4), 253-260. 
FEWTRELL, L. \& KAY, D. (2007b) Quantitative microbial risk assessment with respect to Campylobacter spp. in toilets flushed with harvested rainwater. Water and Environment Journal, 21, 275-280.

FEWTRELL, L., KAY, D. \& MCDONALD, A. (2008) Rainwater harvesting - an HIA of rainwater harvesting in the UK. IN FEWTRELL, L. and Kay, D. (Ed.) Health Impact Assessment for Sustainable Water Management. IWA Publishing, London.

HEALTH AND SAFETY EXECUTIVE (2011) OCE15 Potable water and legionella control. Crown Copyright 2011. http://www.hse.gov.uk/pubns/guidance/oce15.pdf Accessed 14-07-2015

ISLAM, M. M., CHOU, F. N. F., KABIR, M. R. \& LIAW, C. H. (2010) Rainwater: A Potential Alternative Source for Scarce Safe Drinking and Arsenic Contaminated Water in Bangladesh. Water Resources Management, 24, 3987-4008.

JOHNSON, I., LAWTON, E., ATKINSON, C. and ALDOUS, E. (2012) Proposed EQS for Water Framework Directive Annex VIII substances: carbendazim (For consultation). Environment Agency Science Project SC080021/5a(v) conducted by WRc plc, published by Water Framework Directive - UK Technical Advisory Group (WFD-UKTAG), SNIFFER, Edinburgh.

JORDAN, F. L., SEAMAN, R., RILEY, J. J. \& YOKLIC, M. R. (2008) Effective removal of microbial contamination from harvested rainwater using a simple point of use filtration and UV-disinfection device. Urban Water, 5 (3), 209-218, DOI: 10.1080/15730620801977174

JUNGFER, C., SCHWARTZ, T. and OBST, U. (2007) UV-induced dark repair mechanisms in bacteria associated with drinking water. Water Resources, 41, 188-196.

KONIG, K. W. (2001) The Rainwater Technology Handbook: Rainwater Harvesting in building. WiloBrain, Dortmund.

LYE, D. J. (2002) Health Risks Associated with consumption of untreated water from household roof catchment systems. JAWRA Journal of the American Water Resources Association, 38, 1301-1306.

MAGANHA DE ALMEIDA, A. C. and QUILTY, B. (2016) The response of aggregated Pseudomonas putida CP1 cells to UV-C and UV-A/B disinfection. World Journal of Microbiology and Biotechnology, $32,185$.

MDH (2011) Pseudomonas. http://www.health.state.mn.us/divs/eh/water/pseudomonas.html Accessed 14-07-2015

MEERA, V. \& AHAMMED, M. (2006) Water quality of rooftop rainwater harvesting systems: a review. Journal of Water Supply Research and Technology-Aqua, 55 (4), 257-268.

MELVILLE-SHREEVE, P., WARD, S. and BUTLER, D. (2016) Rainwater Harvesting Typologies for UK Houses: A Multi Criteria Analysis of System Configurations. Water, 8 (4), 129-129. DOI:10.3390/w8040129

NHS (2012) Water sources and potential Pseudomonas aeruginosa contamination of taps and water systems: Advice for augmented care units.

http://www.his.org.uk/files/8113/7088/0902/8_DH_Water_sources_and_potential_Pseudomonas_ aeruginosa_contamination_of_taps_and_water_systems_Advice_for_augmented_care_March_201 2.pdf Accessed 14-07-2015

PABLOS, C., MARUGAN, J., VAN GRIEKEN, R. and SERRANO, E. (2013) Emerging micropollutant oxidation during disinfection processes using UV-C, UV-C/H2O2, UV-A/TiO2 and UV-A/TiO2/H2O2. Water Resources. 47, 1237-1245. 
TEXAS WATER DEVELOPMENT BOARD (2005) The Texas Manual on Rainwater Harvesting. http://www.twdb.texas.gov/publications/brochures/conservation/doc/RainwaterHarvestingManual _3rdedition.pdf Accessed 11-12-15

THOMAS, R. B., KIRISITS, M. J., LYE, D. J. \& KINNEY, K. A. (2014) Rainwater harvesting in the United States: a survey of common system practices. Journal of Cleaner Production, 75, 166-173.

WARD, S. (2010) Rainwater harvesting in the UK: a strategic framework to enable transition from novel to mainstream. Unpublished PhD thesis, University of Exeter. Available at: http://hdl.handle.net/10036/106575 Accessed 20593 July 2010.

WARD, S., MEMON, F. A. and BUTLER, D. (2010) Harvested rainwater quality: the importance of appropriate design. Water Science and Technology, 61 (7), 1707-1714.

WORLD HEALTH ORGANISATION (2003) Heterotrophic plate counts and drinking-water safety. IWA Publishing, London. ISBN: 1843390256 (IWA Publishing), ISBN: 9241562269 (WHO)

http://www.who.int/water_sanitation_health/dwq/HPCFull.pdf

Accessed 11-12-15

WORLD HEALTH ORGANISATION (2008) Guidelines for Drinking-water Quality. (electronic version for the web) http://www.who.int/water sanitation health/dwq/fulltext.pdf Accessed 11-12-15

ZHANG, S., YE, C., LIN, H., LV, L. and Yu, X. (2015) UV disinfection induces a VBNC state in Escherichia coli and Pseudomonas aeruginosa. Environmental Science and Technology, 49, 1721-1728. 